\title{
RELATIONSHIP BETWEEN MILKING FLOW RATE AND MILK SOMATIC CELL SCORE IN HOLSTEIN FRIESIAN COWS USING RANDOM REGRESSION ANALYSIS
}

\author{
A.A. Amin \\ Department of Animal Production, Faculty of Agriculture, University of Suez \\ Canal, 41522- Ismailia, Egypt
}

\section{SUMMARY}

Random regression co-variance components of test-day milk somatic cell score $\left(M k_{S C S}\right)$ and milking flow rate $\left(M k_{F R}\right)$ were estimated. Data consisted of 232,570 testday observations from 3864 cows daughters of 3012 dams and 361 sires in $1^{\text {st }}$ lactation recorded between 1998 and 2001 of 73 dairy herds. Multiple-trait random regression animal model used included random animal additive genetic, random permanent environment effects by lactation and days in milk. Estimates of heritabilities of $M k_{S C S}$ and $M k_{F R}$ were around of 0.21 and 0.32, respectively. Additive genetic correlations between early measures of both traits were high and positive. However additive genetic correlations between early and late measures were negative. Permanent environmental correlations were all positive in and showed the lowest differences among estimates than the other correlations. The lowest genetic estimates were obtained during the first 90 to 150 days in milk. Milking flow rate showed the highest estimate of heritability near to lactation end and the highest permanent environmental effect near mid-lactation. Genetic correlations between $M k_{F R}$ and $M k_{S C S}$ at the same DIM were negative and ranged from -0.49 to -0.98 . These results indicated that faster milking cows genetically tend to produce higher quality milk with lower somatic cell concentration. The magnitude of permanent environmental correlations between both traits increased with progressing lactation till the 240 days in milk (-0.57 to -0.80) and then slightly reduced to -0.74 at the end of trajectory. Additive genetic correlations between early measures of $M k_{F R}$ with late measures of $M k_{S C S}$ were considerably high and positive (reaching 0.64). Additive variances in both traits differed significantly, indicating that trait observations during different stages of lactation should not be considered as repeated observations of the same trait. Also current results suggest that achieving goals of genetic selection for improving milk flow rate and reduced milk somatic cell is possible during early lactation months.

Keywords: Somatic cell score, milking flow rate, random regression, permanent environment

Issued by The Egyptian Society of Animal Production 


\section{INTRODUCTION}

Advantages of random regression (RR) test-day models over an approach using 305-day lactation yields are now widely acknowledged. The model for test-day (TD) yields can account more precisely for environmental factors that could affect cows differently during lactation. Random regressions allow for a different shape of lactation curves for each cow. The RR model also allows a cow to be evaluated on the basis of any number of TD records during lactation and it can account for different genetic, permanent environmental and residual variances in the course of lactation. Jaime et al. (2005) recommended the inclusion of random regression coefficients in random regression models to describe permanent environmental effects, in order to define more precisely the genetic and non-genetic effects that influence milk yield.

Several years ago breeding for mastitis resistance (or udder health) was not a common practice in many countries. Recently, an udder health index was introduced in several European countries, based on somatic cell score, milk production traits and milking speed or milking ease. Appearance of a negative correlation between milking speed and clinical mastitis, means that slow milkers suffer more from clinical mastitis (Hiemstra et al., 2000). Although the genetic correlation of milking speed with clinical mastitis is unclear, its correlation with somatic cell score tends to be unfavorable (Boettcher et al., 1998 and Luttinen and Juga, 1997).

Smith et al. (1985) and Lawstuen et al. (1988) each reported heritability estimate for milking flow rate of 0.11 based on a single observation per animal; however, both noted that collection of multiple, repeated observations per animal would be ideal. Meyer and Burnside (1987) also concluded that a single milking flow rate observation per animal may be insufficient, because genetic and environmental factors that affect the milking flow rate of individual cows may vary during lactation or between subsequent lactations. Zwald et al. (2005) reported that cows that milk too slowly will disrupt parlor flow and reduce milking efficiency, but cows that milk too quickly may be at a greater risk for mastitis. Faster milking cows may be undesirable, because an antagonistic relationship may exist between milking flow rate and somatic cell score (Zhang et al., 1994). Therefore most producers prefer cows with moderately milking flow rate that do not decrease the flow of cows through the milking parlor.

The aim of this research work was to examine the relationship between milking flow rate and milk somatic cell score across lactation months using random regression animal model in Hungarian Holstein Friesian cattle.

\section{MATERIALS AND METHODS}

Data consisted of 232570 test-day records (TDR) from 3864 cows daughters of 3012 dams and 361 sires in $1^{\text {st }}$ lactation on milking flow rate $\left(\mathrm{Mk}_{\mathrm{FR}}\right)$ and milk somatic cell score $\left(\mathrm{Mk}_{\mathrm{SCS}}\right)$. The current data set involved the first three lactations of Hungarian Holstein Friesian cows provided by Hungarian Holstein Association. Studied traits were required to be recorded several times across lactation. Cows considered in the current study should have at least five measures. Records were taken on cows that calved between 1998 and 2001. Structure of the data is presented 
in Table 1. Days in milk (DIM) were divided into 12 groups with 30 days interval as shown in Table 1.

Table 1. Overall mean and standard errors with number of test day records (TDR) for milking flow rate $\left(M_{k_{R R m i n}}\right)$ and milk somatic cell score $\left(\mathbf{M k}_{\mathrm{SCS}}\right)$ across days in milk groups

\begin{tabular}{|c|c|c|c|c|c|c|c|c|c|}
\hline \multicolumn{2}{|c|}{ DIM group } & \multirow{2}{*}{$\begin{array}{l}\mathrm{Mk}_{\mathrm{FR}} \\
5.01\end{array}$} & \multirow{2}{*}{$\frac{\mathrm{Mk}_{\mathrm{SCS}}}{1.58}$} & \multirow{2}{*}{$\frac{\text { TDR }}{29840}$} & \multicolumn{2}{|c|}{ DIM group } & \multirow{2}{*}{$\frac{\mathrm{Mk}_{\mathrm{FR}}}{4.89}$} & \multirow{2}{*}{$\frac{\mathrm{Mk}_{\mathrm{SCS}}}{2.69}$} & \multirow{2}{*}{$\begin{array}{l}\text { TDR } \\
18400\end{array}$} \\
\hline 1 & $5-30$ & & & & 7 & $181-210$ & & & \\
\hline 2 & $31-60$ & 5.55 & 1.63 & 28330 & 8 & $211-230$ & 4.60 & 2.69 & 18800 \\
\hline 3 & $61-90$ & 5.27 & 1.95 & 19070 & 9 & $231-260$ & 4.24 & 2.42 & 17760 \\
\hline 4 & $91-120$ & 5.28 & 2.26 & 18400 & 10 & $261-290$ & 4.04 & 3.70 & 17460 \\
\hline 5 & $121-150$ & 5.12 & 2.67 & 17850 & 11 & $291-300$ & 3.94 & 3.20 & 15010 \\
\hline 6 & 151-180 & 5.07 & 2.68 & 18560 & 12 & $>300$ & 3.62 & 3.71 & 13090 \\
\hline \multicolumn{2}{|c|}{ Data Structure } & $\begin{array}{l}\mathrm{La} \\
\text { par }\end{array}$ & & & & & 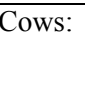 & , S11 & $61\}$ in $1^{\text {st }}$ \\
\hline
\end{tabular}

\section{Statistical analysis}

The random regression model used in the current study was

$$
Y_{i j k l m}=H T D_{i l}+\sum_{n=1}^{n_{p}} \beta_{i l o} \chi_{k l m o}+\sum_{n=1}^{n_{p}} \alpha_{k l o} \chi_{k l m o}+\sum_{n=1}^{n_{p}} \psi_{k l o} \chi_{k l m o}+\varepsilon_{i j k l m}
$$

Where:-

$Y_{i j k l m}$ is the $m^{\text {th }}$ test-day observation of the $k^{\text {th }}$ cow in the $l^{\text {th }}$ lactation, $H T D_{i l}$ is the independent fixed effect of $j^{\text {th }}$ herd-test-date for $l^{\text {th }}$ lactation, $n_{p}$ is the number of parameters fitted on days in milk function, $\beta_{j l o}$ is the $o^{\text {th }}$ fixed regression coefficient

on $j^{\text {th }}$ DIM effect in $l^{\text {th }}$ lactation, $X_{k l m o}$ is the $o^{\text {th }}$ dependent trait on DIM, $\alpha_{k l o}$ is the $O^{\text {th }}$ random regression coefficient of additive genetic effect of $k^{\text {th }}$ cow in $l^{\text {th }}$ lactation

on DIM, $\psi_{k l o}$ is the $o^{\text {th }}$ random regression coefficient of permanent environmental effect of $k^{\text {th }}$ cow in $l^{\text {th }}$ lactation on DIM and $\varepsilon_{i j k l m}$ is the random residual. This model was fitted using the DXMRR procedure applying the software package, DFREML (Karin, 1998 Version 3ß).

The following (co)variance structure was assumed:

$$
V\left[\begin{array}{c}
\alpha \\
\psi \\
\varepsilon
\end{array}\right]=\left[\begin{array}{ccc}
G \otimes A & 0 & 0 \\
0 & P \otimes I & 0 \\
0 & 0 & E \otimes I
\end{array}\right]
$$

where:- $\mathbf{G}=$ genetic covariance matrix between random regression coefficients and traits, $\mathbf{A}=$ additive numerator relationship matrix, $\mathbf{I}=$ identity matrix, $\mathbf{P}=$ permanent environmental covariance matrix among random regression coefficients and traits, and $\mathbf{E}=$ residual variance for lactation $\mathrm{n}$ assumed to be constant throughout the lactation due to program limitations. 


\section{RESULTS AND DISCUSSION}

Heritability estimates and variance components

Somatic cell score: Estimates of heritability and permanent environmental effect for somatic cell score are presented in Figure 1. Estimates of heritability for milk somatic cell score $\left(\mathrm{h}_{\mathrm{Mk}_{\mathrm{SCS}}}^{2}\right)$ ranged from 0.12 to 0.39 and estimates for permanent environmental effect $\left(\mathrm{C}^{2}{ }_{\mathrm{Mk}_{\mathrm{SCS}}}\right)$ ranged from 0.48 to 0.66 . These results are in agreement with those reported by Samore et al. (2002) and Winkelman and Harris (2004). Estimates of $\mathrm{h}^{2}{ }_{\mathrm{Mk}_{\mathrm{SCS}}}$ varied greatly among early, mid, and late lactation. Estimates of $\mathrm{h}^{2}{ }_{\mathrm{Mk}_{\mathrm{SCS}}}$ indicated slight continuous reduction towards the DIM ${ }^{91-120}$ ( 0.12 to 0.13 ) and a marked increase upward to the end of lactation (0.16 to 0.39 ). These results may indicate that selection for improving udder health could be more effective during the $2^{\text {nd }}$ half of lactation which mostly involves the highest rates of mastitis infection (Amin et al., 2004). The current estimates of additive genetic variance for somatic cell score $\left(\sigma_{\mathrm{A}_{\mathrm{SCS}}}^{2}\right)$ increased rapidly with advancing lactation after critical reduction among $\mathrm{DIM}^{31-60}$ to $\mathrm{DIM}^{91-120}$. These results may indicate such development of additive gene action with progression of DIM. The highest contributions of permanent environmental effect on milk somatic cell score were around mid-lactation $\left(\mathrm{DIM}^{91-120}\right.$ to $\left.\mathrm{DIM}^{181-210}\right)$. These results may indicate that improvement of environmental conditions will assist genetic enhancement of udder health.
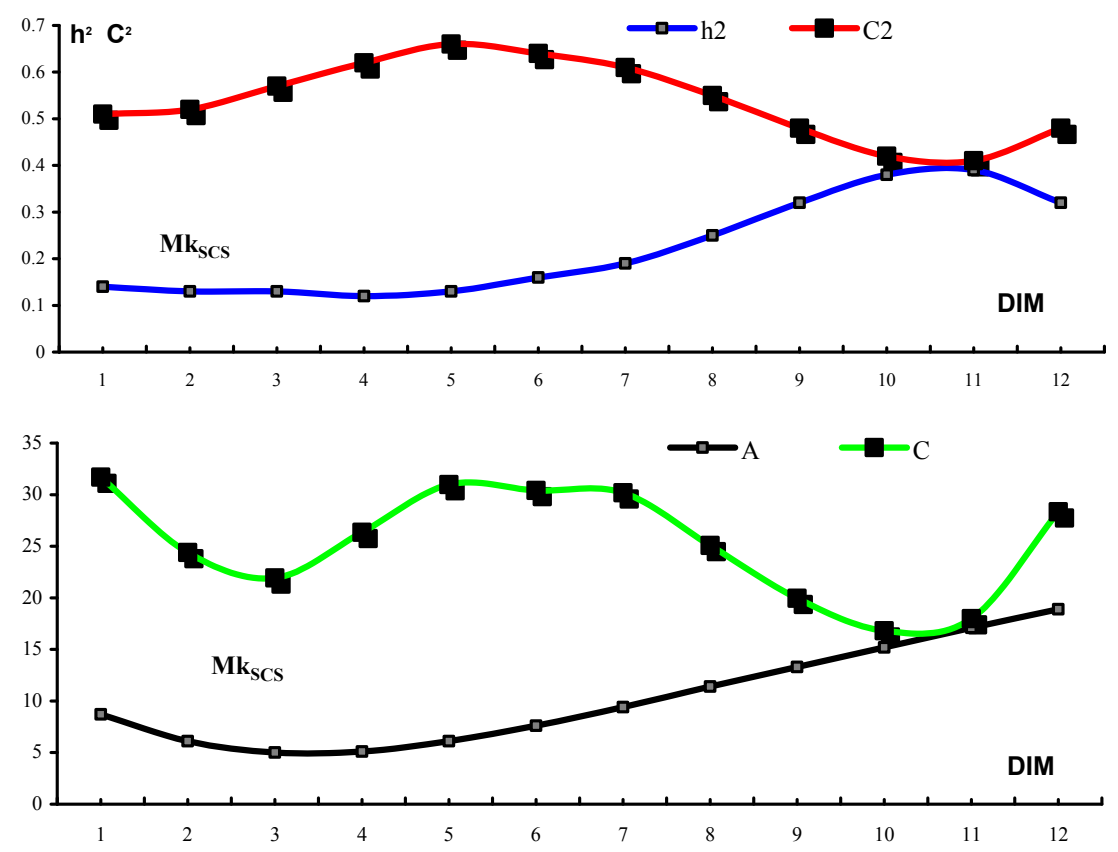

Fig. 1. Estimates of heritability $\left(h^{2}\right)$, permanent environmental effect $\left(C^{2}\right)$, additive (A) and permanent environmental (C) variances across lactation for test-day somatic cell score $\left(\mathrm{Mk}_{\mathrm{SCS}}\right)$ 
Milking flow rate: Estimates of heritability for milking flow rate $\left(\mathrm{h}^{2} \mathrm{Mk}_{\mathrm{FR}}\right)$ ranged from 0.02 to 0.53 while estimates of permanent environmental effect $\left(\mathrm{C}^{2}{ }_{\mathrm{Mk}_{\mathrm{FR}}}\right)$ ranged from 0.36 to 0.72 (Figure 2). Estimates of $\mathrm{h}^{2}{ }_{\mathrm{Mk}_{\mathrm{FR}}}$ were less than 0.1 between $\mathrm{DIM}^{61-}$ 210. On the other hand the corresponding estimates for the $\mathrm{C}^{2}{ }_{\mathrm{Mk}_{\mathrm{FR}}}$ were not less than 0.72. Estimates of additive genetic variance for milk flow rate dropped greatly across DIM $^{61-90}$ to DIM ${ }^{181-210}$ which was associated with magnifying the estimates of permanent environmental effect and resulting in low heritability estimates. However, an opposite trend was observed near the end of lactation. Sprengel et al. (2003) found that heritability of average flow rate ranged from 0.28 to 0.39 across stage of lactation. Similar ranges to the present results for genetic variations in milking flow rate were reported by Tomaszewski, et al. (1975) and Williams et al. (1984). Estimates of permanent environmental variances showed the lowest changes across lactation months with slight increase towards the end of lactation. On the other hand, additive genetic variances for milking flow rate showed considerable reduction during DIM ${ }^{91-210}$ corresponding to the lowest estimates of heritability. Thus, genetic improvement of milking flow rate could be better achieved away from the midlactation. However, increasing milking speed is not totally favored as mentioned in several studies. Luttinen and Juga (1997) concluded that high speeder milking cows are considered unfavorable due to some udder health problems. Therefore, selection for moderate milking flow rate shortly after the mid-lactation seems to have been effective for production, general udder health, and prolonging productive life.
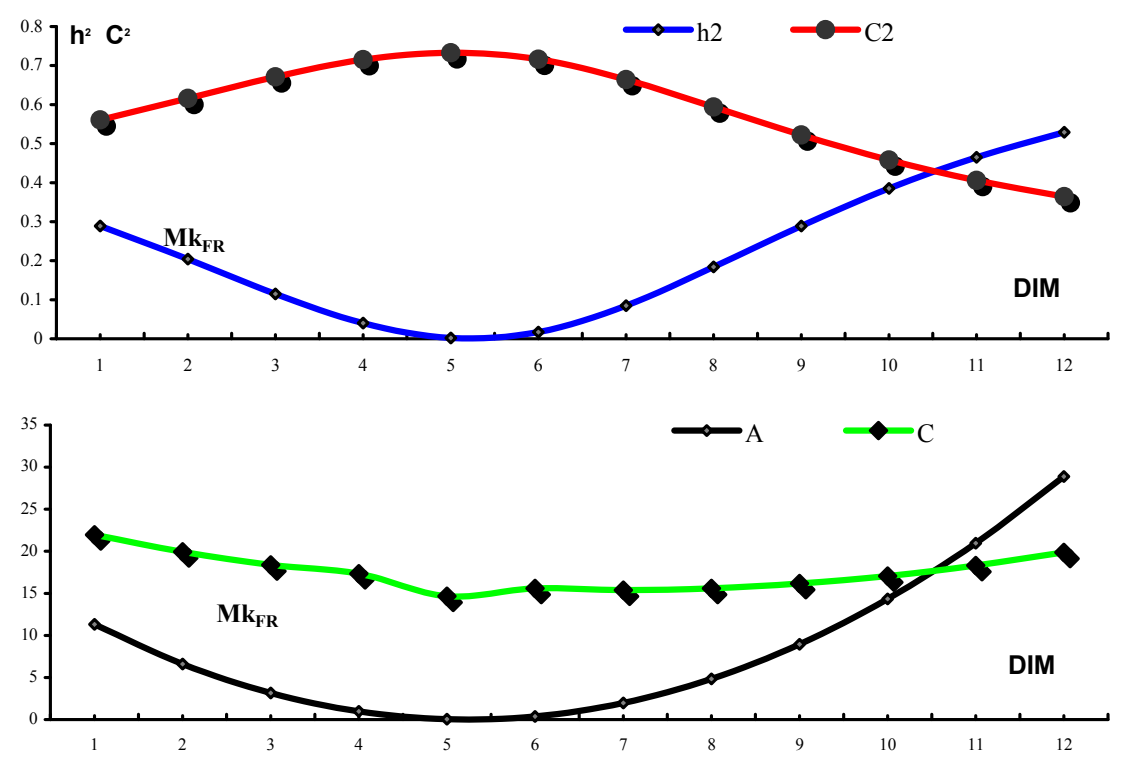

Fig. 2. Estimates of heritability $\left(h^{2}\right)$, permanent environmental effect $\left(C^{2}\right)$, additive (A) and permanent environmental (C) variances across lactation for test-day milking flow rate $\left(\mathrm{Mk}_{\mathrm{FR}}\right)$ 

Additive genetic correlations among measurements within traits across lactation
months

Additive genetic correlations between measurements of milk somatic cell across days in milk are illustrated in Figure 3. Estimates of additive genetic correlations between measures of $\mathrm{Mk}_{\mathrm{SCS}}$ decreased with increasing the interval between test-days. Correlations between measures of $\mathrm{Mk}_{\mathrm{SCS}}$ during the first three DIM's and late DIM near to the lactation end were negative. Negative correlations among measures of $\mathrm{Mk}_{\mathrm{SCS}}$ ranged from -0.08 to -0.64 . The greatest negative correlation occurred between the $1^{\text {st }}$ measure of $\mathrm{Mk}_{\mathrm{SCS}}$ during $\mathrm{DIM}^{5-30}$ with the corresponding measurements during the $2^{\text {nd }}$ half of lactation $\left(\mathrm{DIM}^{>151}\right)$ and ranged from -0.14 to 0.64 . Estimates of negative correlations decreased towards the peak of lactation curve $\left(\mathrm{DIM}^{61-90}\right)$. Additive genetic correlations for milk somatic cell scores during beginning, middle, and at the end lactation were approximately near to unity. These results indicate that similar additive gene expression exists no longer than three months in sequence of lactation. From another genetic point of view, $\mathrm{Mk}_{\mathrm{SCS}}$ could be considered as different traits across lactation. Boettcher et al. (1998) reported that somatic cell score seemed to be the same trait in second and third lactations.

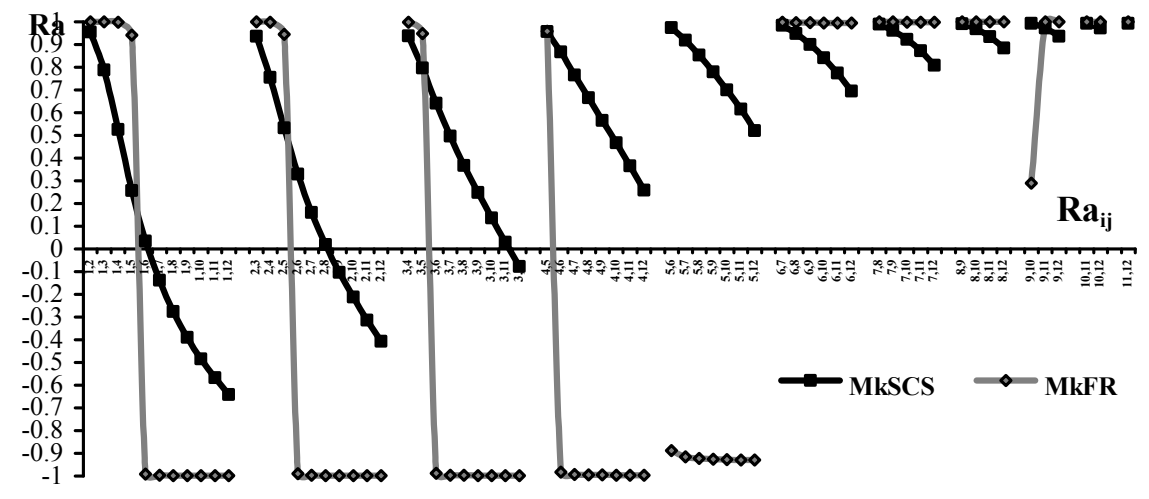

Fig. 3. Estimates of additive genetic $\left(R_{\text {Aij }}\right)$ correlations among measurements (milk somatic cell score and milking flow rate) at ith DIM with the jth reminder DIM across lactation

Winkelman and Harris (2004), using random regression approach found that genetic correlations between the monthly somatic cell score were high $(>0.86)$ but decreased as the length of time between intervals increased. Jaime et al. (2005) found that genetic correlations between individual test days tended to decrease at the extremes of the lactation trajectory, showing values close to unity for adjacent test days. These results tend to indicate that the degree of genetic control of milk somatic cell is not constant over the lactation. In general the current results indicate that genetic control of $\mathrm{Mk}_{\mathrm{SCS}}$ in adjacent measures is almost entirely due to the same genes, and hence is close to be the same trait. 
Estimates of additive genetic correlations between measurements of milking flow rate across DIM groups are presented in Figure 3. Additive correlations between early measures of $\mathrm{MK}_{\mathrm{FR}}$ with the corresponding ones during late lactation showed strong negative values. It appears that cows which initiated lactation with fast milking flow will become slower milking during late lactation. On the other hand, high positive additive correlations of $\mathrm{MK}_{\mathrm{FR}}$ within the last five DIM groups may indicate similar milking flow rate as could be expected. Estimates of additive genetic correlations of $\mathrm{MK}_{\mathrm{FR}}$ were higher than the corresponding estimates for $\mathrm{Mk}_{\mathrm{SCS}}$.

\section{Permanent environmental relationships among measurements within traits}

Estimates of permanent environmental correlations between measurements of each trait in different DIM groups are presented in Figure 4. Permanent environmental correlations with early $\mathrm{Mk}_{\mathrm{SCS}}$ were high and seemed to be in goblet shape. While correlations within the $2^{\text {nd }}$ half of lactation were linear continually decreasing with progressing interval between measures. The lowest permanent environmental correlations were between early with mid-lactation and between midlactation with late lactation measures for $\mathrm{Mk}_{\mathrm{SCS}}$.

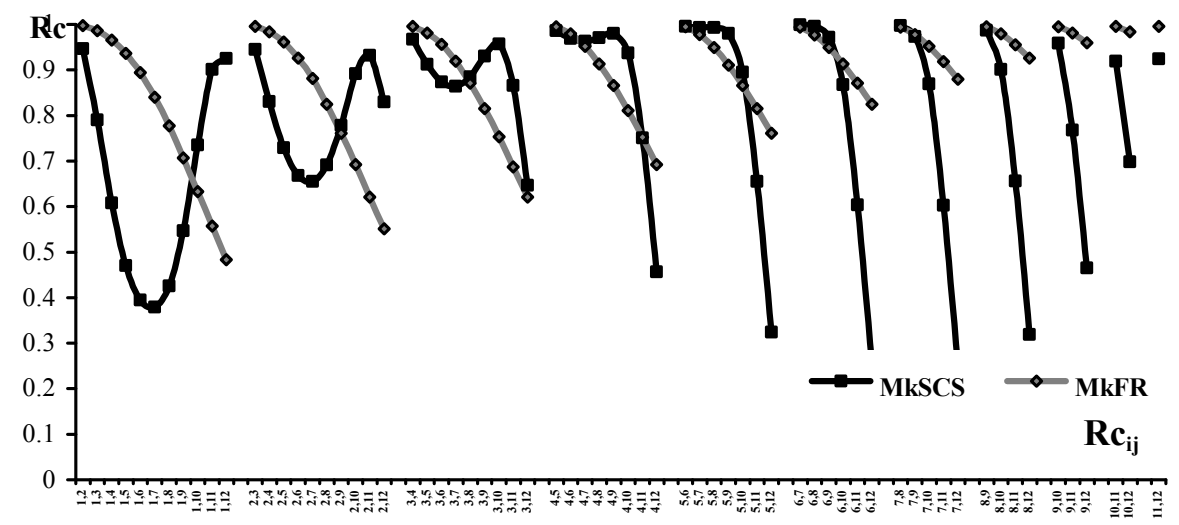

Fig. 4. Estimates of permanent environmental correlations $\left(\operatorname{Rc}_{\mathrm{ij}}\right)$ among measurements (milk somatic cell score and milking flow rate) at ith DIM with the jth reminder DIM across lactation

Estimates of permanent environmental correlations between measurements for $\mathrm{Mk}_{\mathrm{FR}}$ decreased linearly with increasing interval between observations. Results in Figure 4 show that $\mathrm{Rc}_{1,12}$ for $\mathrm{Mk}_{\mathrm{FR}}$ was 0.96 while the corresponding estimate for $\mathrm{Mk}_{\mathrm{SCS}}$ was 0.48 . It appears that, effects of permanent environmental factors on the relationship between early and late measures of $\mathrm{Mk}_{\mathrm{SCS}}$ and $\mathrm{Mk}_{\mathrm{FR}}$ were not similar.

\section{Correlations between milk somatic cell score and milking flow rate}

Correlations between a selected observation of $\mathrm{Mk}_{\mathrm{FR}}$ with the next observations of $\mathrm{Mk}_{\mathrm{SCS}}$ were defined as non-identical correlations $\left({ }^{\mathrm{NI}} \mathrm{R}\right)$ as shown in Figure 5. Estimate of correlations between measures of $\mathrm{Mk}_{\mathrm{FR}}$ with measures of $\mathrm{Mk}_{\mathrm{SCS}}$ at the 
same point of days in milk across lactation were identical correlations $\left({ }^{\mathrm{I}} \mathrm{R}\right)$. Estimates of ${ }^{\mathrm{NI}} \mathrm{R}$ additive relationships of $\mathrm{MK}_{\mathrm{FR}} * \mathrm{Mk}_{\mathrm{SCS}}$ tended generally to be negative across more than $3 / 4$ of lactation. Negative additive genetic correlations among $\mathrm{Mk}_{\mathrm{SCS}} * \mathrm{Mk}_{\mathrm{FR}}$ ranged from -0.49 to -0.98 that increased in magnitude with decreasing interval between measures. It appears that low milk somatic cell may be associated with speeder milking cows during $\mathrm{DIM}^{90}$ till the lactation end. On the other hand, positive additive correlations (the $1^{\text {st }}$ three lines in Figure 5) were observed between measures of $\mathrm{Mk}_{\mathrm{FR}}$ during the first $\mathrm{DIM}^{90}$ with measures of $\mathrm{Mk}_{\mathrm{SCS}}$ from DIM $^{120}$ till the lactation end. Positive additive correlations ranged from 0.13 to $0.64,0.34$ to 0.47 and 0.02 to 0.09 within the first three DIM, respectively. These results suggest that early fast milking cows tend to produce milk with elevated SCS during the late of lactation. Thus early slower milking cows may become less susceptible to mastitis infection during the late of lactation. Jamrozik et al. (1998) using random regression analysis found that genetic correlations between production traits and somatic cell score were small and positive (unfavorable) in $1^{\text {st }}$ and negative in $2^{\text {nd }}$ and $3^{\text {rd }}$ lactations.
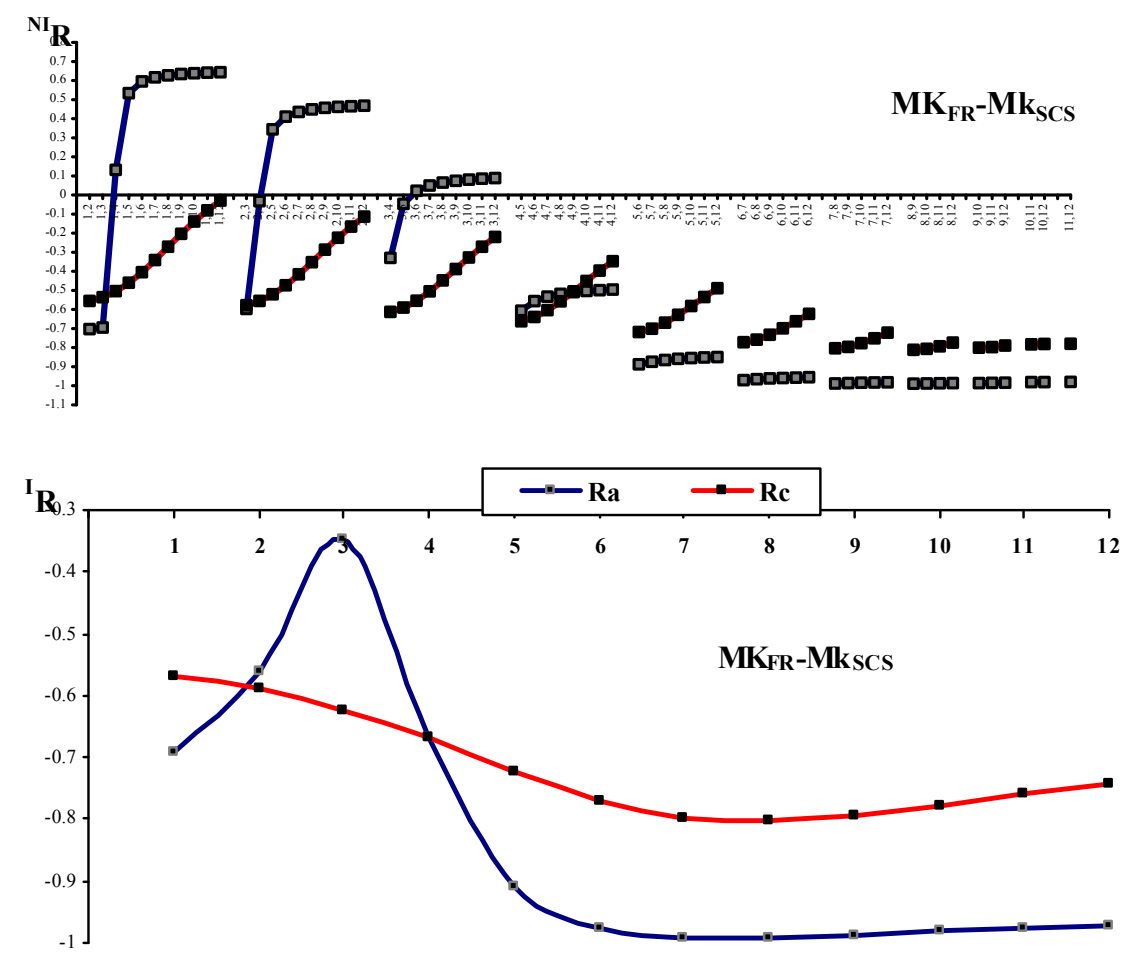

Fig. 5. Estimates of random regression additive genetic and permanent environmental correlations among identical (IM) and non-identical measures (NIM) of both traits across lactation 
Estimates of ${ }^{\mathrm{I}} \mathrm{R}$ Additive genetic correlations between $\mathrm{Mk}_{\mathrm{FR}}$ and $\mathrm{Mk}_{\mathrm{SCS}}$ within the same DIM group (among identical measurements) were all negative. These correlations seemed to be extremely high during the flat shape across the $2^{\text {nd }}$ half of lactation, magnitude being more than -0.94 . Therefore, breeding programs and genetic strategies favoring fast milking could be recommended to increase milk quality.

Negative permanent environmental correlations $\left({ }^{\mathrm{NI}} \mathrm{R}\right)$ prevailed between measures of $\mathrm{Mk}_{\mathrm{FR}} * \mathrm{Mk}_{\mathrm{SCS}}$ across lactation and ranged from -0.03 to -0.81 . Permanent environmental correlations between identical measurements of $\mathrm{Mk}_{\mathrm{FR}} * \mathrm{Mk}_{\mathrm{SCS}}$ was lower and less sloping than the corresponding additive curve within the $2^{\text {nd }}$ half of lactation. Therefore, it appears that $\mathrm{MK}_{\mathrm{FR}} * \mathrm{MK}_{\mathrm{SCS}}$ are more genetically controlled while early environmental control for moderately milking speed could keep udder in good health across lactation. Boettcher et al. (1998) found that genetic correlations between milking speed and somatic cell score ranging from 0.25 to 0.41 in the first three parities. The positive correlation indicated that bulls which sired cows that milked faster also tended to sire cows that had greater SCS. This result is not surprising, because one would logically predict that easier exit of milk out of the udder and teat canal is associated with easier entry of pathogens into the udder. Several other researchers (Lund et al., 1994; Zhang et al., 1994; Monardes et al., 1990 and Seykora and McDaniel, 1985) have also reported an unfavorable association between somatic cell score and various measures of milking speed. The lower correlation between milking speed and somatic cell score in later lactations may have resulted because milking flow rate was recorded in first lactation. Another explanation is that somatic cell score may be a different trait genetically in first versus later lactations. Jamrozik et al. (1998) reported that all within lactation environmental correlations between production traits and somatic cell score were negative.

\section{Correlation among estimates of expected breeding values}

Correlations between estimates of expected $\left(\mathrm{R}_{\mathrm{EBV}}\right)$ breeding values of $\mathrm{Mk}_{\mathrm{FR}}$ and $\mathrm{Mk}_{\mathrm{SCS}}$ are presented in Figure 6 in two separate graphics. The right hand graph shows correlations between identical measures of EBV of the both traits $\left({ }^{\mathrm{I}} \mathrm{R}_{\mathrm{EBV}}\right)$, while the left hand graph shows correlations between measurements of EBV within traits $\left({ }^{\mathrm{NI}} \mathrm{R}_{\mathrm{EBV}}\right)$. Most of correlations $\left({ }^{\mathrm{NI}} \mathrm{R}_{\mathrm{EBV}}\right)$ between early and late estimates are strong and negative during the first 120 days in milk for both traits being higher in magnitude than -0.80 (left hand lines, Figure 6). Strong positive correlations existed between estimates during the late of lactation and ranged from 0.67 to 0.98 . Correlations between estimates of EBV changed from negative to positive sign across middle of lactation $\left(\mathrm{DIM}^{121-150}\right)$. These results may indicate that estimates of correlations of EBV of both traits are not consistent in value and/or direction across lactation months. High positive $\mathrm{R}_{\mathrm{EBV}}$ was noticed between the nearest measures of both traits across the $2^{\text {nd }}$ half of lactation. It appears that $\mathrm{Mk}_{\mathrm{SCS}}$ and MkFR are inversely transmitted across successive generation of selection programs constructed based on information during early lactation months.

Estimates of ${ }^{\mathrm{I}} \mathrm{R}_{\mathrm{EBV}}$ between $\mathrm{MK}_{\mathrm{FR}}$ and $\mathrm{Mk}_{\mathrm{SCS}}$ (Figure 6: left hand graph) were negative during most lactation months ( ${ }^{\mathrm{I}} \mathrm{R}_{\mathrm{EBV}}$ at last $\mathrm{DIM}^{3}$ were positive). The highest 
negative correlations were obtained during $\mathrm{DIM}^{90}$ and during $\mathrm{DIM}^{181-260}$ and ranged from -0.30 to -0.50 and from -0.32 to -0.38 , respectively. Positive correlations between estimates of EBV for both traits during the last three DIM groups did not exceeded 0.37 . Therefore, selection for improving milking flow rate during the late lactation months will be associated with increase of SCS and then reduce milk quality.

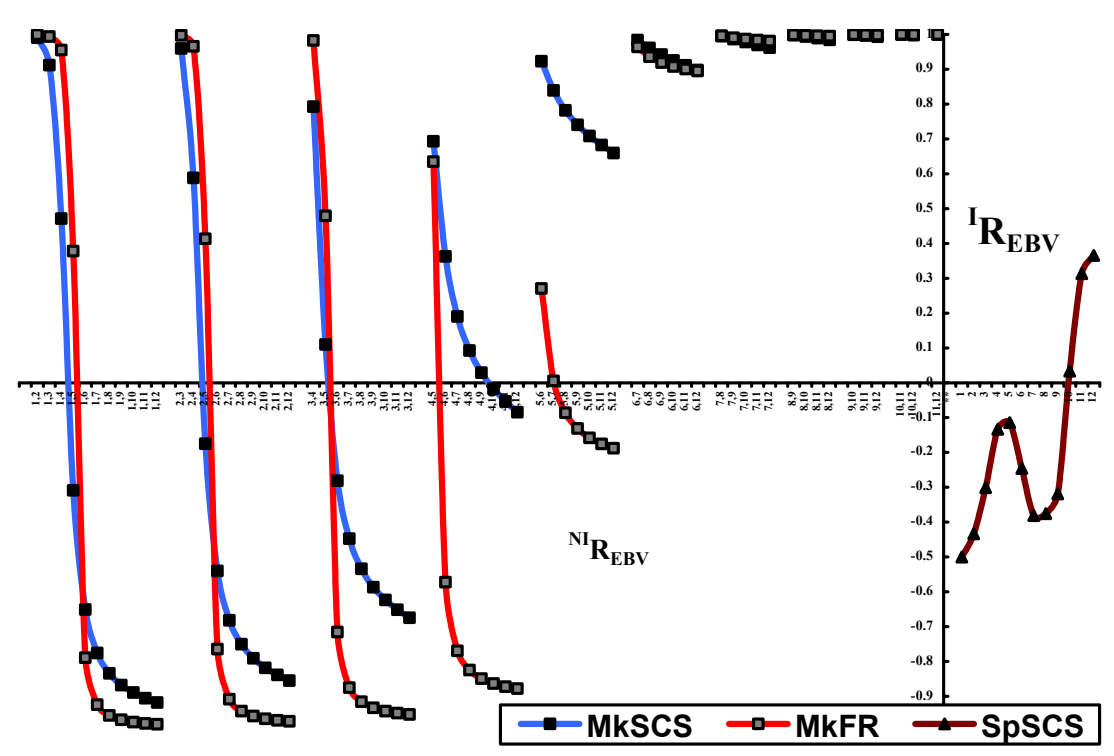

Fig. 6. Estimates of correlations between measures of expected breeding values (EBV) across lactation

\section{REFERENCES}

Amin A.A., N. S. Hassan and A. Abdel-Ghany, 2004. Genetic analysis for the relationship between udder-teat malformed with their milk production and somatic cell concentration of Holstein Friesian. using animal model. The $29^{\text {th }}$ International Con. for Stat. Comp. Sci. and its Appl.. Cairo-Egypt April 17-22.

Boettcher, P.J., J.C.M. Dekkers and B. W. Kolstad1, 1998. Development of an udder health index for sire selection based on somatic cell score, udder conformation, and milking speed. J. Dairy Sci. 81:1157-1168.

Hiemstra, A, A.B Groen, H. Bovenhuis, B. Ducro and G. Jong, 2000. Estimation of covariances between mastitis incidence, somatic cell count, udder conformation and milk production in Dutch Holstein Friesian dairy cattle. Animal Breeding and Genetics Group, Wageningen Institute of Animal Sciences (WIAS), Wageningen University, Wageningen, The Netherlands. 
Jaime A.C., R.F. Euclydes and P.S. Lopes, 2005. Estimation of genetic parameters for test-day milk yield in Holstein cows using a random regression model. Genet. Mol. Biol. 28 (1) 1451-1467.

Jamrozik, J, L.R. Schaeffer and F. Grignola, 1998. Genetic parameters for production traits and somatic cell score of Canadian Holsteins with multiple trait random regression model. Proc 6. WCGALP 23:303-306.

Lawstuen, D. A., L.B. Hansen, G.R. Steuernagel and L. P. Johnson, 1988. Management traits scored linearly by dairy producers. J. Dairy Sci. 71:788-799.

Lund, T., F. Miglior; J.C.M. Dekkers, and E. B. Burnside 1994.. Genetic relationships between clinical mastitis, somatic cell count, and udder conformation in Danish Holsteins. Livest. Prod. Sci. 39:243-251.

Luttinen, A. and J. Juga, 1997. Genetic relationships between milk yield, somatic cell count, mastitis, milkability and leakage in Finnish dairy cattle populations. Proceedings International Workshop on Genetic Improvement of Functional Traits in cattle (GIFT)-Health. Uppsala. INTERBULL bulletin 15: 78-83.

Meyer, K., 1998. " $\mathrm{D}_{\mathrm{X}} \mathrm{M}_{\mathrm{RR}}$ " a program to estimate covariance functions for longitudinal data by restricted maximum likelihood in proceeding $6^{\text {th }}$ WCGA 12 16 Jan. University New England, Armidale, 27: 465-466. Last modified : Jan. 24, 2000

Meyer, K., and E. B. Burnside, 1987. Scope of a subjective assessment of milking speed. J. Dairy Sci. 70:1061-1068.

Monardes, H. G., R. I. Cue, and J. F. Hayes, 1990. Correlations between udder conformation traits and somatic cell count in Canadian Holstein cows. J. Dairy Sci. 73:1337-1342.

Samoré, A.B; P. Boettcher, J. Jamrozik; A. Bagnato and A.F. Groen, 2002. Genetic parameters for production traits and somatic cell scores estimated with a multiple trait random regression model in Italian Holsteins. 7th World Congress on Genetics Applied to Livestock Production, August 19-23, Montpellier, France

Seykora, A. J. and B. T. McDaniel, 1985. Heritabilities of teat traits and their relationships with milk yield, somatic cell count, and percentage of two-minute milk. J. Dairy Sci. 68: 2670-2683.

Smith, S. P., F. R. Allaire, W. R. Taylor, H. E. Kaeser and J. Conley, 1985. Genetic parameters and environmental factors associated with type traits scored on an ordered scale during first lactation. J. Dairy Sci. 68:2058-2071.

Sprengel, D., J. Dodenhoff; K.U. Gotz, J. Duda and L. Dempfle, 2003. International genetic evaluation for milkability traits. Dept. of Animal Sci. Tu-Munchen, Germany.

Tomaszwski, M.A.; G.L. Hargrove, and J.E. Legates, 1975. An assessment of filed measures of milking rate. J. Dairy Sci. 58: 545.

Williams, C.B., E.B. Burnside, and L.R. Schaeffer, 1984. Genetic and environmental parameters for two field measures and milking speed. J. Dairy Sci. 67:1273-1280.

Winkelman, A. M. and B. L. Harris, 2004. Somatic Cell Score Test-day Model for National Genetic Evaluation "Random Regression Models for Genetic Evaluation of Somatic Cell Score in New Zealand Dairy Sires". Livestock Improvement Corporation.-interbull.slu.se/bulletins/bulletin32/Harris.pdf

Zhang, W. C., J.C.M. Dekkers, G. Banos and E. B. Burnside, 1994. Adjustment factors and genetic evaluation for somatic cell score and relationships with other traits of Canadian Holsteins. J. Dairy Sci. 77:659-665. 
Zwald, N.R., K. A. Weigel, Y.M. Chang, R. D. Welper and J. S. Clay, 2005. Genetic evaluation of dairy sires for milking duration using electronically recorded milking times of their daughters. J. Dairy Sci. 88:1192-1198. 
العلاقة بين معدل تدفق اللبن وتقيرات الخلايا الجسدية فى أبقار الهولوستين فيرزيان باستخدام تحليل الاعتماد العشوائى.

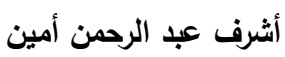

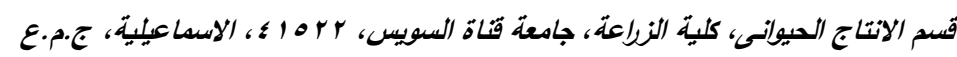

تم تقدير مكونات التباين والتغاير الاعتماد العشوائى للاختبار اليومى لنقدير الخلايا الجسدية فى اللبن

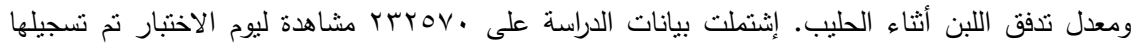

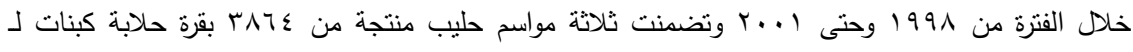

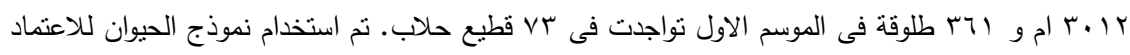

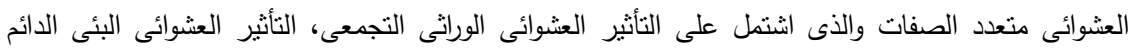

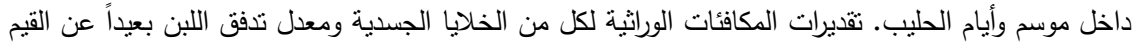

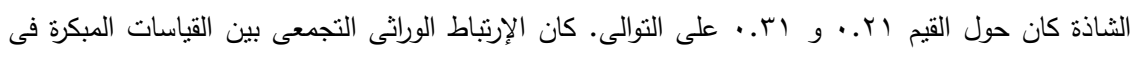

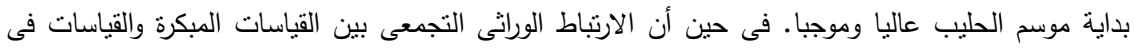

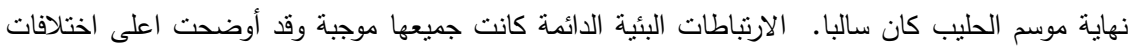

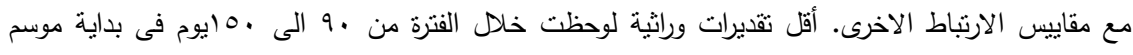

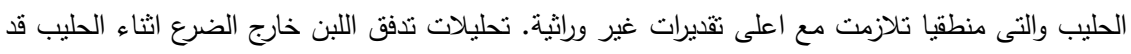

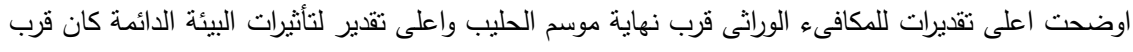

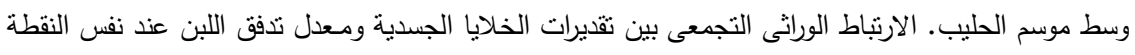

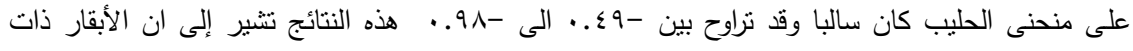

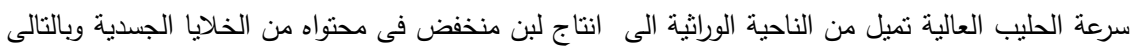

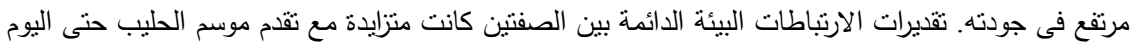

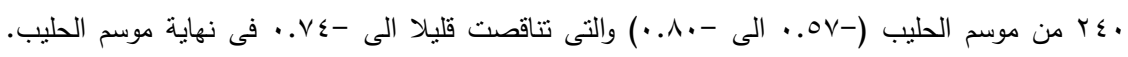

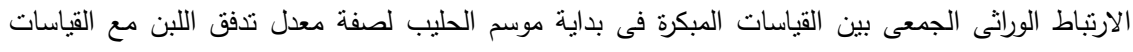

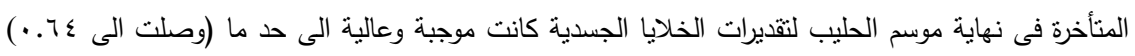
• التباينات الوراثية التجمعية فى كل من الصفتين كانت مختلفة معنوياً والتى تنثير الى أن المثاهدات الثيات أثناء

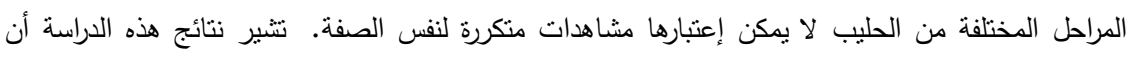

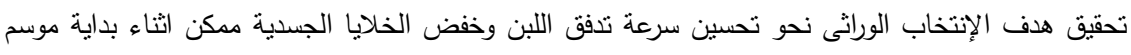

